\title{
REVIEW
}

\section{Modelling microbial food webs}

\author{
Keith Davidson* \\ Swansea Algal Research Unit, School of Biological Sciences, University of Wales, Swansea, Singleton Park, \\ Swansea SA2 8PP, Wales, UK
}

\begin{abstract}
Microbial processes are now perceived to be an important component of the marine food chain. Mathematical models present a quantitative means of analysing interspecies interactions within food webs. Although detailed models of individual components of the microbial food web (bacteria, phytoplankton, protozoan predators) have been derived, their incorporation into large-scale food web models has yet to become commonplace. Current models have confirmed the general importance of microbial food webs and that the specific inclusion of protozoan predators in models is often necessary to simulate the observed dynamics. Simulations have indicated that the effect of the microbial food web on the food chain may vary greatly depending on imposed physical or biological conditions. The manner in which nutrient regeneration from protozoan predators and its subsequent reutilisation by bacteria and phytoplankton is simulated is an important consideration. Models employ equations of varying sophistication, but detailed recent formulations use a dual model currency of $C$ and $N$. Models have also increased our understanding of the interaction between grazing and nutrient cycling and the different behaviour of food chains and webs.
\end{abstract}

KEY WORDS: Mathematical models Microbial loop P Protozoan predators

\section{INTRODUCTION}

Since Azam et al. (1983) proposed the existence of a 'microbial loop' the microbial food web has become increasingly recognised as an important component of the aquatic food chain. A representation of the microbial food web is given in Fig. 1. Bacteria and phytoplankton compete for mineral nutrients, and are preyed on by a variety of protozoans which are themselves ingested by mesozooplankton predators. Bacteria utilise dissolved organic matter (DOM; a large fraction of which is released from phytoplankton) and compete with the phytoplankton for mineral nutrients. The major consumers of bacteria are thought to be small $(<5 \mu \mathrm{m})$ non-pigmented flagellates (Capriulo et al. 1991), however, other protists also prey on bacteria.

- Present address: Department of Statistics \& Modelling Science, University of Strathclyde, Livingstone Tower, 26 Richmond St, Glasgow G1 1 XH, Scotland, UK.

E-mail: keith@stams.strath.ac.uk
Phytoplankton are grazed by heterotrophic dinoflagellates, ciliates and tintinnids, as well as metazoan grazers such as copepods and rotifers. Processes such as mixotrophy (Boraas 1988), nutrient regeneration in both refractory and non-refractory forms (Flynn \& Davidson 1993), cannibalism by flagellates (Fenchel 1982), prey selection (Stoecker et al. 1986, Flynn et al. 1996), the action of viruses (Suttle 1994) or more complicated $N$ cycling pathways (Jumars et al. 1989) further complicate the picture. The dynamics of the food web and the relative fractions of nutrients retained, lost and recycled remain uncertain.

As discussed by Pommeroy (1991) food webs are inherently difficult to analyse as they contain too many parameters to be amenable to simple calculus, but too few to allow the implementation of statistical techniques. However, mathematical models provide tools which allow investigation of complex dynamical systems such as microbial food webs (Ducklow \& Taylor 1991). Models can be used both to analyse a system. perhaps to gain a better understanding of a particular 


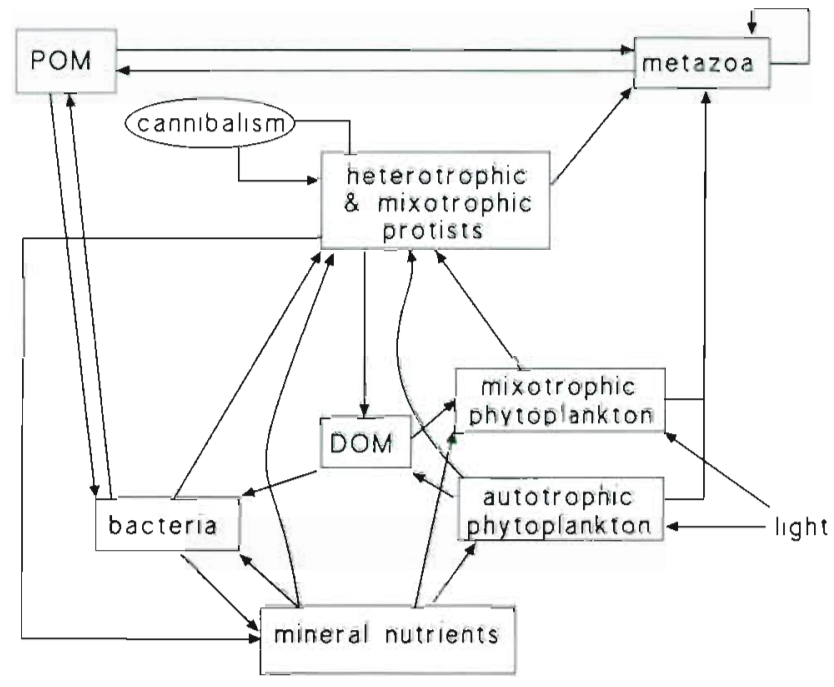

Fig. 1. Representation of the major pathways within the microbial loop. POM: particulate organic matter; DOM: dissolved organic matter

interaction such as the utilisation of alternative nutrient sources by phytoplankton, and also to predict the future behaviour of an ecosystem under a variety of conditions.

Models of marine ecosystems have been reviewed by Fasham (1993) and (for the North Sea) Fransz et al. (1991). Such models are often quite general and do not contain a realistic representation of the microbial food web. Here, I review models of the major components of the microbial food web (bacteria, phytoplankton, protozoan predators) in isolation (models of monocultures) and in combination (models of inter-species interactions and food webs)

\section{MODELS OF BACTERIA}

Monod (1942) proposed a model for microbial growth which related the specific growth rate of the population to the concentration of the yield limiting nutrient in the culture medium by a rectangular hyperbola of the form:

$$
\mu=\mu_{\max } \frac{S}{K_{\mathrm{s}}+S}
$$

where $\mu$ is the specific growth rate with maximum $\mu_{\max }$ at infinite $S, S$ is the concentration of nutrient in the medium and $K_{\mathrm{s}}$ the half-saturation constant (Fig. 2). The dynamic behaviour of Monod's model in chemostat systems was studied by Koga \& Humphrey (1967) who found it to be overdamped for all realistic parameter values. It remains the most common method of simulating bacterial growth

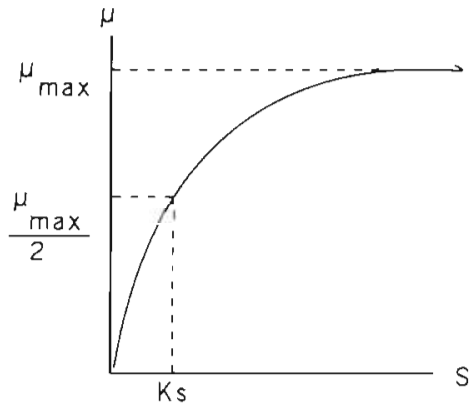

Fig. 2. Rectangular hyperbola as described by Eq. (1). $\mu_{\max }$ : maximum specific growth rate $K_{i}$ : half-saturation constant; $S$ : concentration of nutrient in the medium

The major success of the model has been in describing the growth of bacterial populations, although it has also been applied to steady state algal growth (Grover 1991). Numerous studies have produced modified models incorporating further physiological and/or physical factors. For example, Ramkrishna et al. (1967) compared modified Monod models and more detailed formulations which included a degree of structure in the protoplasmic mass and Billen \& Fontigny (1987) included the uptake of amino acids and dissolved proteins.

However, more complete investigation of bacterial cell physiology, perhaps in order to determine the flux of $\mathrm{C}$ and $\mathrm{N}$ in a food web, requires more detailed formulations. Recently, Thingstad and co-workers investigated, as part of a larger study, aspects of the microbial food web (Thingstad \& Pengerud 1985, Pengerud et al. 1987. Thingstad 1992). They produced a model of bacteria in aquatic environments which related growth to the concentration of both $\mathrm{C}$ and $\mathrm{N}$ in the medium using a combination of 2 rectangular hyperbolas:

$$
\mu=\mu_{\max } \frac{\mathrm{N}}{K_{\mathrm{N}}+\mathrm{N}} \frac{\mathrm{C}}{K_{\mathrm{C}}+\mathrm{C}}
$$

where $K_{\mathrm{V}}$ and $K_{\mathrm{c}}$ are the half-saturation constants for uptake of $\mathrm{N}$ and $\mathrm{C}$, respectively.

Bacterial models using quota type equations (Caperon 1968a, b. Droop 1968) allowed intracellular nutrient levels to be considered. For example, Thingstad (1987) investigated the effect of variable $\mathrm{N}: \mathrm{C}$ and $\mathrm{P}: \mathrm{C}$ ratios in the medium. Uptake $(V)$ of $C$ was now described as

$$
V=V_{\max } \frac{Q_{\max }-Q_{C}}{Q_{\text {max }}-Q_{\min }} \frac{C}{K_{C}+C}
$$

where $V_{m i x}$ is the maximum uptake rate and $Q_{C}$ is the carbon quota with maximum $Q_{\max }$ and minimum $Q_{\text {min }}$ Analogous equations were written for $N$ and $P$. Cell number growth was then made a function of the nutrient with cell quota closest to its minimum. 
Further refinement to bacterial models includes the work of Fasham et al. (1990) and Ducklow \& Fasham (1992) who included a relationship to balance the uptake of dissolved organic nitrogen (DON) and ammonium [and related this to the utilisation of dissolved organic carbon (DOC)]. A more descriptive model of bacterial growth relating to pelagic systems is that of Hopkinson \& Vallino (1994) which simulates nutrient composition of the cell.

As highlighted by Fasham et al. (1990) one of the critical factors in a food web model containing bacteria is the fraction of primary production which cycles through the bacterial component. A potentially important factor in a model is therefore the loss of nutrient from a cell through nutrient regeneration. Bacterial $N$ regeneration was simulated by Goldman et al. (1987) by relating it to the $\mathrm{C}: \mathrm{N}$ ratio of both the substrate and the bacteria and the gross growth efficiency. This equation was first used in aquatic systems by Fenchel \& Blackburn (1979) and has also been used for bacteria by Lancelot \& Billen (1985) (a similar equation for protozoa will be discussed at greater length below).

\section{MODELS OF PHYTOPLANKTON}

\section{Quota type models}

The inability of the Monod model to describe the experimental chemostat data of Caperon (1968a, b) and Droop (1968) for 2 green flagellates Isochrysis galbana and Pavlova (Monochrysis) lutheri, respectively, led them to seek a new explanation of algal growth. the Caperon/Droop (quota) model (Fig. 3). These authors suggested a compartment model in which steady state algal growth was a function of the nutrient within the cells. Caperon (1968b) proposed a function of the form:

$$
\mu=\mu_{\max } \frac{Q-Q_{0}}{K_{\mathrm{q}}+\left(Q-Q_{0}\right)}
$$

where $\mu_{\max }$ is the maximum achievable specific biomass growth rate, $\mu, Q$ is the cell quota defined as intracellular nutrient per unit biomass, $Q_{0}$ is the minimum value of $Q$, and $K_{4}$ is the half-saturation constant for growth. This equation reduces to Droop's (1968) equation on making the assumption that $K_{\mathrm{q}}=Q_{0}$

The quota model has been successful in predicting (at least in steady state) the growth of various species limited by a range of single nutrients including vitamin B12, phosphate, silicate, nitrate, ammonium and iron. The basic model has been modified to account for numerous other facets of growth and environmental conditions such as dual nutrient limitation and the effect of light limitation (see the review by Tett \& Droop 1988).

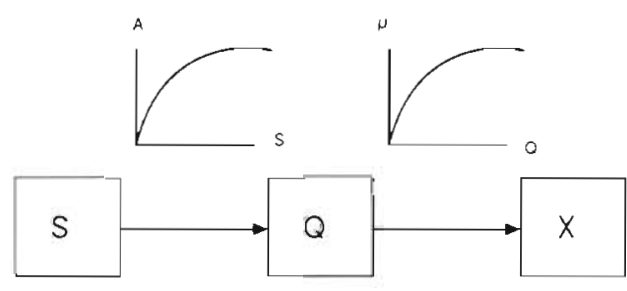

Fig. 3. Schematic representation of the Caperon/Droop (quota) model of algal growth. A: uptake rate per unit biomass; $S$ extracellular nutrient concentration; $Q$ : cell quota $\mu_{\mathrm{max}}$. maximum specific rate of biomass increase; $X$ : biomass Extracellular nutrient is converted to intracellular nutrient as a hyperbolic function of $S . Q$ intracellular nutrient per unit biomass. Biomass increase is a hyperbolic function of $Q$

Unfortunately, the quota model has been less successful in simulating transient growth. Droop (1975) achieved reasonable success in simulating batch culture data for Monochrysis lutheri only if the lag phase was neglected. Furthermore, Burmaster (1979) found the quota model incapable of adequately describing the changes in cell number density following step changes in dilution in a chemostat for phosphatelimited $M$. lutheri.

Recently Davidson et al. (1993) found the quota model to be inadequate to represent $\mathrm{C}, \mathrm{N}$ and cell numbers in their laboratory batch cultures of Isochrysis galbana. They derived a nutrient processing model which simulated semi-independently the dynamics of $\mathrm{C}$ and cell numbers by introducing a processing time during which newly absorbed $\mathrm{N}$ is unavailable to promote cell division. This allowed simulation of both time lags prior to cell division and variations in $\mathrm{C}_{\text {cell }}{ }^{-1}$ with time without significant increase in model complexity compared to a quota formulation.

Quota models or similar formulations such as the nutrient processing model are relatively simple but maintain a degree of biological realism and are easily parameterisable. These models are therefore are potentially useful as the phytoplankton sub-model in larger ecosystem models.

A variety of other phytoplankton growth models have been derived. These range from empirical relationships (Collos 1986) to models which represent a considerable degree of cell physiology (Shuter 1979). However, as discussed below, many of these models are not easily incorporated into large ecosystem simulation models.

\section{'Compartment' phytoplankton models}

Multiple nutrient pool models incorporate a chain of intracellular compartments. A number of such models have been reviewed by Cunningham \& Maas (1978). 
Later formulations include those of Demanche et al. (1979) who attempted to model the dual use of nitrate and ammonium and Riegman \& Muir (1984) who related growth rate to the nutrient in the first of 2 intracellular compartments. These models are quite descriptive in nature and a major drawback is that parameterisation is no easy task as the model compartments are not always physically or biochemically identifiable within the cell.

Attempts have been made to simulate transient cell number data by introducing a time lag into the growth function of a quota type model (Caperon 1969, Cunningham 1984). However, such a lag introduces dynamical instabilities and formally violates nutrient conservation (Grenney et al. 1973).

\section{Growth/irradiance models}

Phytoplankton growth/irradiance models seek to relate growth rate to indicators of nutritional status such as the chlorophyll:C ratio or to photosynthetic parameters such as optical cross section and quantum yield for photosynthesis (Laws \& Bannister 1980, Kiefer \& Mitchel 1983, Laws \& Chalup 1990 and others). As pointed out by Cullen (1990) these models involve numerous parameters not all of which can be routinely measured, and fall strictly in the domain of steady state growth. They are therefore, as yet, unsuitable for use in predator/prey or ecosystem modelling studies. Before they can be more widely applied, the robustness of the underlying assumptions in transient conditions requires testing. Such work is now being undertaken, e.g. Cullen et al. (1993).

\section{MODELS OF PROTOZOA}

Protozoan micro- and dinoflagellates present a link which allows the transfer of primary production up the food chain. They can exhibit autotrophic or heterotrophic growth or mixotrophy and are able to regenerate nutrients at high weight specific rates.

Micro- and dinoflagellates have occasionally been modelled as part of the phytoplankton (Andersen et al. 1987, Andersen \& Nival 1988). Predatory heterotrophic protozoa are usually modelled in terms of their predator/prey interactions and are discussed below.

\section{PREDATOR/PREY INTERACTIONS}

The traditional equations to represent predator/prey interactions are the Lotka-Volterra equations derived by Lotka (1925) and Volterra (1926). Modified versions of these equations relating them specifically to microbial growth (by simulating a chemostat) were proposed by Bungay \& Bungay (1968).

\section{Bacteria/grazer models}

An early modelling study by Canale (1970) investigated the ingestion of bacteria by comparing the dynamics of the Lotka-Volterra equations with 2 alternative models. These were first, an equation to describe the rate of change of the yield limiting nutrient, and second, saturating Monod type functions for both prey (bacteria) and predator (protozoan) growth. Canale (1973) then attempted to simulate batch and continuous cultures of a bacterium and a ciliate. Although the Lotka-Volterra model was capable of simulating the general response of the system, it was unable to reproduce transients. Sudo et al. (1975) extended this work by introducing the possibility of bacterial flocculation and deflocculation. They found that the introduction of such an inhomogeneity was necessary to allow simulation of their experimentally observed oscillations. Comparison between the Lotka-Volterra model and a 'double Monod' type model was also made by Tsuchiya et al. (1972). They found the steady states reached for a particular parameter set by the Monod type model were independent of initial conditions, whereas those of the Lotka-Volterra model were not.

A variety of factors which could potentially affect the dynamics and stability of food web models have been studied using bacteria/grazer models. For example, Jost et al. (1973) introduced an ' $\mathrm{S}$ ' shaped ingestion function. The inclusion of respiration and death into the equations was proposed by Fredrickson et al. (1973) in a model which extended the food chain to include primary producers, herbivores and carnivores. These factors were also considered by Villareal et al. (1975) and Wilcox \& MacCluer (1979). Fredrickson (1977) details various factors which affect the dynamics of mixed cultures of microorganisms, including predation, and other interactions such as commensalism and amensalism.

Nisbet et al. (1983) suggested the introduction of predator endogenous metabolism into 'double Monod' models would increase stability. More recently, a number of papers by Sambanis (see Sambanis \& Fredrickson 1988) developed a model to account for the coexistence of ciliates and bacteria in continuous culture. Saprotrophy (the growth of bacteria on products of lysis) and bacterial wall growth were highlighted as potential means of imparting stability in the predatorprey cultures

Applications of Lotka-Volterra equations to marine food chains include Thingstad \& Sakshaug (1990) who 
investigated nutrient enrichment in food webs and Stoecker \& Evans (1985) who considered competition by 2 ciliate grazers feeding on a dinoflagellate. Umorin (1992) formulated a model for competition between bacterivorous flagellates and bacterivorous ciliates in continuous culture. He found it necessary to allow flagellates to feed on both dissolved organic matter and bacteria to prevent their elimination from the system.

The ability of relatively simple model formulations to simulate experimental data sets of bacterial/grazer systems indicated that modelling of more complete ecosystems was indeed feasible. However, model instability encountered when stable single species (Monod) models were combined to represent predator/prey situations pointed to potential problems in the derivation of large-scale models when output may not easily be related to the initial model assumptions.

\section{Phytoplankton/grazer models}

Grazing of phytoplankton by protozoa and zooplankton has also been studied. Most of the models in this category consider nutrients, phytoplankton and herbivores (N-P-H models) and investigate a particular interaction between species without considering the growth dynamics of the individual species in particularly great detail. A number of models specifically sought to examine grazing response and therefore tackled the problem of potential model instability mentioned in the previous section. These included:

Steele \& Henderson (1981), who compared hyperbolic and ' $S$ ' shaped grazing functions.

Franks et al. (1986), who recognised that saturating functional responses (such as rectangular hyperbolas) have a potentially destabilising effect on a model. They proposed the use of a modified version of the function proposed by Mayzaud \& Poulet (1978), in which grazing rate did not saturate at high prey densities as it gave a more stable response than a saturating function in transient conditions. An alternative method to represent ingestion was suggested Berrymann (1992) and others who proposed that ingestion was a function of the predator/prey ratio rather than simply prey density. Further work investigating various ingestion functions (Type I and II functional response and preydependent vs ratio-dependent grazing) was carried out by Carpenter et al. (1993) by applying them to a field data set.

Hofmann \& Ambler (1988), who produced a model in which copepod grazing on phytoplankton was considered in detail. Two phytoplankton size classes and 5 copepod development stages were included. Ingestion of phytoplankton was based on a modified Ivlev function:

$$
I_{1}=I_{\mathrm{m} \lambda}\left(1-e^{-Y_{1} E P N_{1}}\right)
$$

where $I$ is the ingestion rate with maximum $I_{\mathrm{m} u} \gamma$ is a constant, EPN is the effective food concentration and the subscript $i$ denotes the copepod feeding category. The study found a number of factors including the temporal scale of a particular event (e.g. the frequency of nutrient input) to be important in determining the dynamics.

Frost (1987), who assessed the effect of 2 types of grazers: micro- and mesozooplankton. His model was tested against field data from the subarctic Pacific Ocean. Various grazing hypothesis were implemented and tested. Herbivorous microzooplankton were predicted to be the major grazers of the phytoplankton with mesozooplankton existing as indiscriminate grazers.

A number of more biologically detailed models of phytoplankton/grazer interactions have been derived. In general, these models investigate the effect of particular aspects of cell physiology on the system. Carpenter \& Kitchel (1984) developed a model which took account of phytoplankton size distribution. Cell growth was related to $\mathrm{C}$ content and the half-saturation to cell radius. The model predicted variability in herbivorous zooplankton size and abundance was a function of food web interactions not nutrient supply. This led to variations in primary productivity of up to 2 orders of magnitude. The work was extended by Bartell et al. (1988) who found variations in productivity were determined primarily by grazing and nutrient regeneration.

The choice of model currency in terms of carbon, nitrogen cell numbers or a combination of these was highlighted by Davidson et al. (1995) who modelled the interaction between a phytoplankter and a dinoflagellate. Phytoplankton growth was described in terms of $\mathrm{C}, \mathrm{N}$ and cell numbers, based on the model of Davidson et al. (1993). The model's ability to simulate laboratory experimental data was found to be significantly better if phytoplankton $\mathrm{C}$ cell ${ }^{-1}$ was allowed to vary: indicating a degree of cell structure was required in the model.

\section{Multiple trophic levels}

Phytoplankton-based food chains have recently been used to investigate the interaction between different trophic levels. Thingstad \& Sakshaug (1990) used steady state Lotka-Volterra equations to represent phytoplankton-based food chain webs. In the food web model, 2 size classes of phytoplankton were included. Large algae could be ingested by copepods and small algae by protozoa. By analytically determining steady states the authors investigated nutrient 
enrichment and cycling through sedimentation and mixing. In a linear food chain, enrichment sustained an increasing number of trophic levels. In the food web a dominant linear food chain of small algae, protozoa, copepods and fish developed until nutrient levels were sufficient to allow the growth of large phytoplankton. The control of a particular population was thought to be a function of the entire ecosystem rather than limitation by a single nutrient or grazing by a single predator.

Frost \& Franzen (1992) extended Thingstad \& Sakshaug's (1990) work by considering grazing and iron limitation in the control of phytoplankton. They used chemostat type equations as an analogue for an equatorial upwelling zone. Phytoplankton, herbivores and 2 species of secondary carnivores were included. Grazing control was a necessary feature of the model, but a combination of grazing and nutrient limitation generated the observed sub-optimal phytoplankton growth rates under optimal conditions. Armstrong (1994) then developed a model with multiple food chains, based on different size classes using allometric relations. He found that multiply linked food chains were more realistic than independent food chains and that nutrients could limit the number of classes but grazing would limit the size of each class.

Evans \& Parslow (1985) produced an N-P-H model which made a significant advance by introducing seasonality and an equation for the change in the depth of the mixed layer. Ingestion of phytoplankton was made a hyperbolic function of prey density above a threshold concentration. The authors investigated the dynamics of their model by removing levels of complexity and studying a simplified version of the model. They found wind driven mixing and grazing to be responsible for the seasonal cycle of phytoplankton and that the shallowing of the mixed layer was not always necessary to initiate a spring bloom. The form of the annual cycle was closely related to the midwinter phytoplankton growth rate, a difficult parameter to measure experimentally. The model was further extended by Evans (1988) to include an extra phytoplankton group

\section{MODELS OF THE MICROBIAL FOOD WEB}

Many aquatic ecosystem models do not, as yet, include a detailed description of the microbial food web (which I will define as a minimum of: bacteria, phytoplankton and protozoan predators). I will restrict my review to the relatively few models which do contain microbial components.

Initial models were quite descriptive in design. These included the model of Laake et al. (1983). The model (based on Monod kinetics) contained bacteria, flagellates, ciliates and dissolved substrate. 'Selectivity coefficients' were introduced to distinguish ciliate grazing on bacteria and flagellates. The model confirmed phagotrophy by heterotrophic flagellates to be an important process as its inclusion was necessary to generate the observed decline in bacterial density. The model of Pace et al. (1984) included protozoan grazers in a complex system of 17 compartments and 73 fluxes. Their simulations indicated that a representation of the microbial food web was a necessary component of the model. Subsequent models have investigated particular aspects of the microbial food web.

\section{Predation by protozoa}

Thingstad \& Pengerud (1985) simulated the microbial loop using both Monod and quota type models representing chemostat conditions. They examined the effect of culture conditions and combinations of bacteria, algae and protozoa. The protozoan predators were found to be important to the system both in terms of their predatory behaviour and their ability to regenerate nutrients. The use of a quota model, although complicating the analysis, introduced a degree of flexibility into the model. The authors proposed that still more complicated models would be necessary to account for more realistic growth conditions.

The importance of prey ingestion by protozoa was highlighted again recently by Ducklow (1994). He compared the model of Fasham et al. (1990) (which contained many components of the microbial loop but not an explicit representation of protozoa) to a revised version of the same model (Ducklow \& Fasham 1992) which did incorporate a protozoan compartment. The dynamics of the 2 models differed with respect to ammonium regeneration. The mean predicted bacterial biomass was found to be lower when protozoans were explicitly modelled (Fig. 4).

\section{Nutrient cycling}

In addition to Thingstad \& Pengerud (1985) a number of other studies have found regeneration and cycling of nutrients to be important. Parsons \& Kessler (1986) found the recycling of organic material to be an important pathway in (and heterotrophic flagellates to be an important component of ) their model of the upper mixed layer.

Moloney et al. (1986) employed a more detailed representation of the microbial food web. Microbial compartments were found to be important with bacteria acting as mineralisers of $\mathrm{N}$ to sustain phytoplankton growth, and zooflagellates and large protozoa regen- 


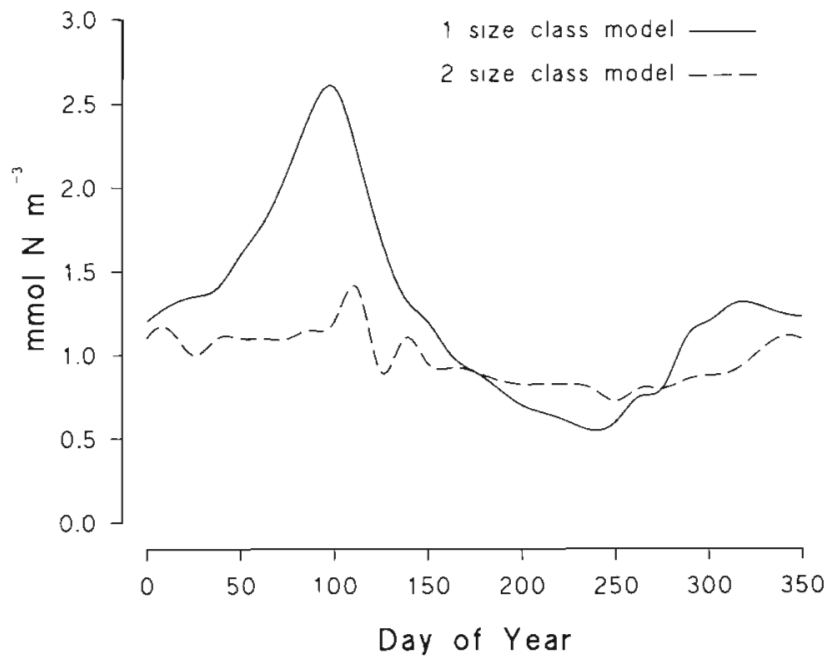

Fig. 4. Comparison of the models of Fasham et al. (1990): the 1 predator size class model, and Ducklow \& Fasham (1992): the 2 predator size class model. Bacterial biomass measured as $\mathrm{mmol} \mathrm{N} \mathrm{m}^{-3}$ was lower in the 2 size class model, where protozoan predators were explicitly represented. Redrawn from Ducklow (1994)

erating significant quantities of $\mathrm{N}$ during a phytoplankton bloom. If no regeneration of nutrients was allowed, a single phytoplankton peak and low protozoan biomass were predicted by the model (Fig 5a). However, if $\mathrm{N}$ cycling was permitted, 2 phytoplankton peaks due to new and regenerated production (the 2 peaks shown in Fig 5b, respectively) were predicted as well as a considerably higher protozoan yield. Newall et al. (1988) applied Moloney et al.'s (1986) model to determine the effect of different conditions on nutrient cycling. Differences in the behaviour of models of the pycnocline and the euphotic zone were observed, with considerable $\mathrm{N}$ being made available by the action of microheterotrophs at the pycnocline.

Fasham (1985) developed a flow analysis model which incorporated both $\mathrm{C}$ and $\mathrm{N}$ under steady state conditions. He assumed phytoplankton and bacteria competed for nutrients. Simulations indicated the importance of nutrient regeneration from both protozoa and zooplankton.

\section{Physiological models of nutrient regeneration}

A number of more detailed physiological models have been developed to investigate the temporal effects of variation in $\mathrm{N}$ regeneration rate.

Caron \& Goldman (1988) and Caron et al. (1990) related protozoan nutrient regeneration to the nutritional status $(\mathrm{C}: \mathrm{N})$ ratio of the prey. They developed an equation similar to that of Goldman et al. (1987) for bacteria which was discussed above:

$$
E=\frac{R}{1-G G E}\left(\frac{1}{C: N_{\text {prey }}}-\frac{G G E}{C: N_{\text {pred }}}\right)
$$

where $E$ is the excretion rate, $R$ the respiration rate and GGE the gross growth efficiency.

Landry (1993) modified Eq. (6) to account for nutrient assimilation efficiency. However, as pointed out by Caron \& Goldman (1993), difficulties exist in parameterising such a modification.

Anderson (1992) and Davidson et al. (1995) produced models for nutrient regeneration based on intracellular nutrient status. Anderson's (1992) model, which is applied to bacteria, protozoa and copepods, assumes that non-nitrogenous substrates are preferentially used for respiration, thereby conserving nitrogen for
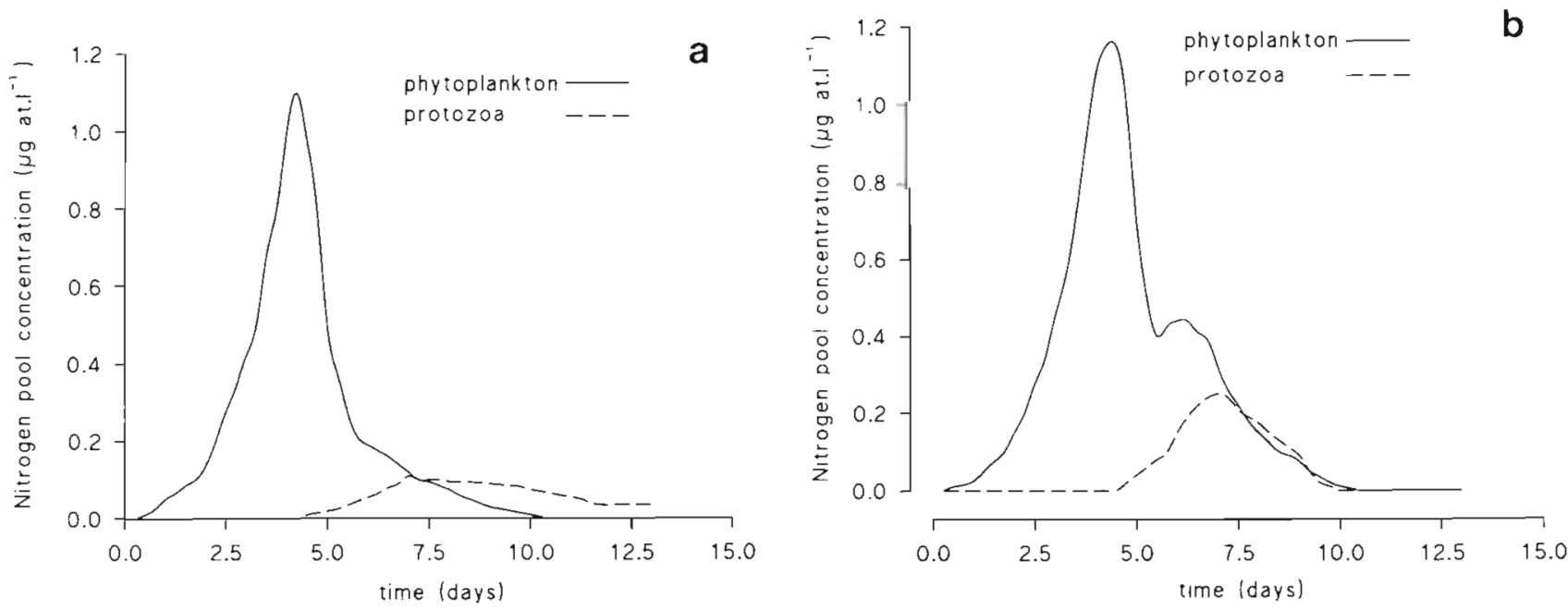

Fig. 5. Output of Moloney et al.'s (1986) model (a) without and (b) with N remineralisation included, showing phytoplankton and protozoan N content. Redrawn from Moloney et al. (1986) 
growth. In contrast, based on their experimental results with the dinoflagellate Oxyrrhis marina in which they observed $\mathrm{N}$ to be continually regenerated, Davidson et al. (1995) related $N$ regeneration to an optimal C: $N$ ratio, using the equation:

$$
E=\left(m_{1} \frac{N \Theta}{O x} p_{1}\right) \frac{1}{\Theta}
$$

where $m_{1}$ and $p_{1}$ define the rate of $C$ respiration, $N$ is cellular nitrogen, $O x$ is the concentration of the dinoflagellate and $\Theta$ is the optimal $C: N$ ratio 16.5 for Oxyrrhis marina). If the $\mathrm{C}: \mathrm{N}$ ratio is higher than optimal, excess $C$ is respired or voided and if it is lower then excess $\mathrm{N}$ is regenerated.

Eq. (7) simulated their data sets better than Eq. (6) (Fig. 6) when both were incorporated in a dynamic model framework. The major difference between the 2 formulations is that Caron \& Goldman's (1988) equation uses a constant GGE which is unrealistic in transient situations.

\section{Predation/nutrient regeneration in food webs}

The simple phytoplankton/grazer models discussed above indicated that primary producers may be limited simultaneously by grazing and nutrients. Such an interaction cannot be studied by simple observation. The models detailed below have been used to study this interaction and have further confirmed the importance of nutrient regeneration within ecosystems.

Stone (1990) was able to explain the seemingly paradoxical release of extracellular organic carbon by phytoplankton under nutrient stress ffirst examined

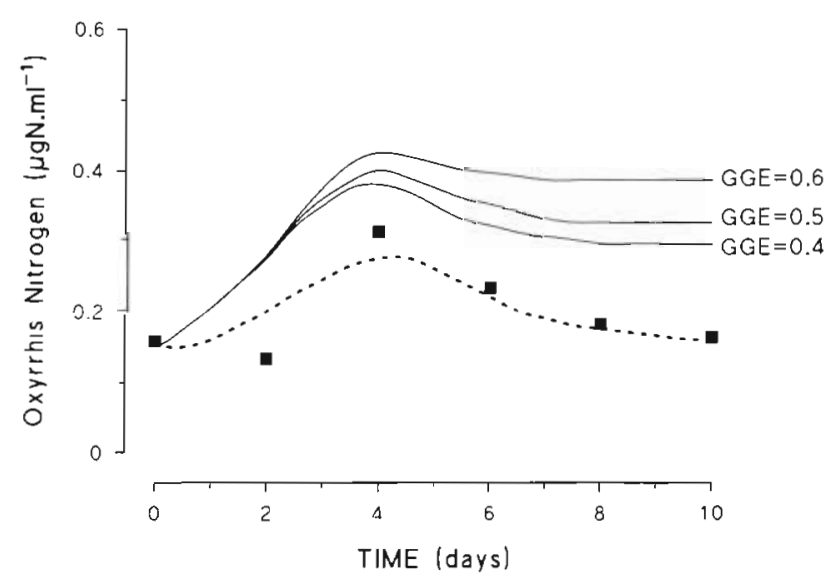

Fig. 6. Oxyrrhis marina. Comparison of predicted $N$ content using a dynamic predator prey model including Eq. (6) (solid lines) and Eq. (7) (dashed line) to simulate protozoan nutrient regeneration. Three values of $O$. marina gross growth efficlency (GGE), bracketing the experimentally observed value, were used with Eq. (6). Redrawn from Davidson et al. (1995) using a model by Bratbak \& Thingstad 1985, see also Ietswaart \& Flynn 1995) using a theoretical matrix model. Grazing by protozoa on bacteria and subsequent rapid recycling of nutrients was found to reduce competitive pressure from the bacteria and created conditions in which the phytoplankton equilibrium density increased

A carbon-based model (of a salt marsh estuary) was used by Wright et al. (1987) to address the link/sink question in steady state. Substrate concentration, bacteria, heterotrophic microflagellates and zooplankton were simulated using Monod type equations along with growth yields. Using steady state solutions the relative roles of substrate and grazing control of bacterial densities were investigated. This model predicted that either grazing or substrate limitation would occur independently of the other, with the former acting as a link to higher trophic levels and the latter acting as a sink. (The development of other models of estuarine microbial food webs was reviewed by Christian \& Wetzel 1991.)

King (1987) formulated a steady state model of the open ocean to examine the interaction between grazing and nutrient cycling. The model predicted that the importance of nutrient cycling would increase with the number of trophic levels and the excretion to ingestion ratio of the predators.

Lancelot et al. (1991a, b) combined 3 previously published models. For phytoplankton bacterioplankton and physical conditions. They then investigated carbon cycling in the marginal ice zone of the ScotiaWeddell Sea. Further work (Lancelot et al. 1993) found that the phytoplankton bloom was controlled by wind mixing and protozoan grazing.

\section{Alternative ecosystem model structures}

A variety of other modelling strategies have been employed to represent ecosystems incorporating microbial food webs. As pointed out by Fasham (1993) not only the values of state variables but also the intercompartment flows are of interest when analysing the output of a model. Microbial models which use network analysis to estimate the flux of nutrients between compartments include Vézina \& Platt (1988) and Ducklow et al. (1989).

Descriptive models which attempt to represent in some detail the perceived major food web interactions include that of Taylor \& Joint (1990). Their model included both nitrate and ammonium as well as DOC and detritus. The model predicted that bacteria were unimportant in determining the efficiency of the food web in steady state stratified conditions. BarettaBekker et al. (1994) produced a model similar to that of 
Taylor \& Joint (1990) but considered transient rather than steady state conditions by incorporating a standard organism in terms of $\mathrm{C}, \mathrm{N}$ and $\mathrm{P}$. Heterotrophic flagellates were included as the link between bacteria and microzooplankton, whereas Taylor \& Joint (1990) made microzooplankton graze bacteria directly.

Size-based models have been proposed by Moloney \& Field (1991a). These authors grouped populations on the basis of size, with predators acting on the size class below. Their model uses a common structure for each size class with parameters calculated using allometric relationships. Using this model Moloney et al. (1991) found the microbial food web to be more important as a carbon source in oceanic rather than coastal ecosystems. Furthermore, the microbial food web was found to contribute on average in excess of $75 \%$ of regenerated N. Further developments of this model have continued (eg. Moloney 1992, in which chain forming diatoms are included, and Painting et al. 1993, who look at species succession in the southern Benguela upwelling region).

\section{DISCUSSION}

The perceived importance of the microbial loop indicates that inclusion of protozoa in ecosystem models may often be necessary. However, the simulation of protozoa as a separate entity from the zooplankton in ecosystem models remains relatively rare.

Mathematical models may be either mechanistic or empirical in design. However, the complexity of a microbial food web and indeed of its component parts is such that mechanistic models are almost exclusively employed. The design of a particular model may vary greatly and depends on the particular purpose of the modelling exercise, as modelling of an ecosystem as a whole and modelling of the physiology of the individual biotic and abiotic components are carried out with different objectives and often using different approaches.

Mechanistic microbial models may be subdivided into 2 general categories: descriptive and analytical. Descriptive models attempt to represent the system of interest in a detailed manner including as many as possible of the factors which are involved. In contrast, analytical models represent the system in as simple a manner as is possible, with the condition that the model is still sufficiently detailed to capture the important features of the dynamics. Good analytical models are not easily formulated, as difficult decisions must be made regarding what should and should not be included in the model. However, they potentially produce results which are easier to interpret than those obtained from descriptive models.
Models of individual species may also be analytical or descriptive in character. Analytical models are useful to predict features such as growth rates and cell yields. These may be of use to biotechnologists for predicting culture behaviour, or to ecologists for predicting the expected density or biamass content of a spring bloom given a known nutrient loading Descriptive models seek to answer (or pose new) questions about particular aspects of physiology. They often contain a degree of biochemical speculation and are of most use in the analysis of laboratory datasets

Whole ecosystem models are not readily produced from a combination of single species models as complexity becomes too great to allow an analysis of model behaviour. Instead, analytical models are derived which seek to represent the interaction between biotic and abiotic compartments. The art in producing such models is to include sufficient detail to produce a realistic simulation while keeping the model simple enough that one can hope to analyse and understand the reasons for a particular model prediction

\section{Models of single species}

Simple analytical and descriptive physiological models of bacteria and phytoplankton have been produced. Early formulations were simple in design, relating cell number yields and growth rates to parameters such as extracellular nutrient concentration. However, some of these formulations have proved remarkably enduring and representations of both bacterial and algal steady state growth have been produced in the form of the Monod and quota models, respectively, which are adequate for many purposes. These models are capable of predicting nutrient uptake rates, cell (or biomass) growth rates and cell (or biomass) yields.

A common implementation of the quota model has been to predict growth rates (Tett \& Droop 1988) of algal cultures. However, the poor transient behaviour of the quota model (Grover 1991, Davidson et al 1993) indicates that models with a better temporal response are required to represent short-term temporal fluctuations or the response of a population to a pulse of nutrient (perhaps due to an upwelling event) Notwithstanding this shortcoming, the quota model may well be adequate to represent phytoplankton growth in steady state or slowly varying transient conditions, but as yet has rarely been used in this manner (exceptions are Sharples \& Tett 1994 and Tett \& Walne 1995).

Table 1 shows that quite simple bacterial and phytoplankton models are often adopted in food web 
Table 1. Microbial food web component of models. assim: assimilation; C: carbon; conc: concentration; const: constant; dept dependent; DOC: dissolved organic carbon; DON: dissolved organic nitrogen; egest: egestion; excr: excretion; ext: extracellular; fn: function; graz: grazing; hyp: hyperbolic; mort: mortality; N: nitrogen; phyto: phytoplankton; pred: predator; prop: proportional; respn: respiration

\begin{tabular}{|c|c|c|c|c|c|}
\hline Model & Bacterial growth $\mathrm{fn}$ & Phyto growth fn & Protozoan growth fn & Ingestion fn & Regeneration fn \\
\hline Laake et al. (1983) & Modified Monod & Not modelled & Modified monod & As growth fn & Not modelled \\
\hline $\begin{array}{l}\text { Thingstad \& Pengerud } \\
\text { (1985) (Model 1) }\end{array}$ & $\begin{array}{l}\text { Combined Monod } \\
\text { ( } C \text { and } \searrow \text { ) }\end{array}$ & Monod & $\begin{array}{l}\text { Yield } \times \text { hyp } \\
\text { ingestion }\end{array}$ & $\begin{array}{l}\text { Hyp in of } \\
\text { bacterial numbers }\end{array}$ & $\begin{array}{l}\text { Const per } \\
\text { bacteria eaten }\end{array}$ \\
\hline $\begin{array}{l}\text { Thingstad \& Pengerud } \\
\text { (1985) (Model 2) }\end{array}$ & Quota & Monod & $\begin{array}{l}\text { Fn of cell } \\
\text { nutrients }\end{array}$ & $\begin{array}{l}\text { hyp fn of } \\
\text { bacterial numbers }\end{array}$ & $\begin{array}{l}\text { Fn of protozoan } \\
\text { C:N ratio }\end{array}$ \\
\hline $\begin{array}{l}\text { Parsons \& Kessler } \\
(1986)\end{array}$ & $\begin{array}{l}\text { Monod type fn } \\
\text { modified for loss } \\
\text { by resp }\end{array}$ & $\begin{array}{l}\text { Monod type fn } \\
\text { modified for loss } \\
\text { by resp }\end{array}$ & $\begin{array}{l}\text { Hyp fn of } \\
\text { bacterial numbers }\end{array}$ & As growth fn & $\begin{array}{l}\text { Const fraction } \\
\text { (zooplankton } \\
\text { only) }\end{array}$ \\
\hline $\begin{array}{l}\text { Moloney et al. (1986) } \\
\text { (flow model) }\end{array}$ & $\begin{array}{l}\text { Asymptotic fins of } \\
N \text { uptake - losses }\end{array}$ & $\begin{array}{l}\text { Hyp fn of } \\
\text { Nuptake - losses }\end{array}$ & $\begin{array}{l}\text { Const } \times \text { prey } \times \\
\text { pred }\end{array}$ & As growth fn & const fraction \\
\hline Wright et al. (1987) & Monod type & Not modelled & Monod type & As growth fn & Not modelled \\
\hline Fasham et al. (1990) & $\begin{array}{l}\text { Fn of ext } N+ \\
\text { DON - losses }\end{array}$ & $\begin{array}{l}\text { Fn of light and } \\
\left(\mathrm{NH}_{4}, \mathrm{NO}_{3}\right)\end{array}$ & $\begin{array}{l}\text { Not modelled } \\
\text { explicitly }\end{array}$ & $\begin{array}{l}\text { Hyp fn and food } \\
\text { preference }\end{array}$ & Const fraction \\
\hline Taylor \& Joint (1990) & $\begin{array}{l}\text { Monod fn of } \\
\text { DOC }\end{array}$ & $\begin{array}{l}\text { Combined fn of } \\
\mathrm{NO}_{3} \text { and } \mathrm{NH}_{4}\end{array}$ & Prop to food conc & As growth fn & Const fraction \\
\hline $\begin{array}{l}\text { Lancelot et al. } \\
(1991 \mathrm{a}, \mathrm{b})\end{array}$ & $\begin{array}{l}\text { Fn of substrate } \\
\text { conc }\end{array}$ & Intracellular pool & Not modelled & $\begin{array}{l}\text { Temperature dept } \\
\text { lnear equation }\end{array}$ & Not modelled \\
\hline $\begin{array}{l}\text { Moloney \& Field } \\
(1991 \mathrm{a}, \mathrm{b})\end{array}$ & $\begin{array}{l}\text { Hyp uptake } \\
\text { fn - losses }\end{array}$ & $\begin{array}{l}\text { Hyp uptake } \\
\text { fn-losses }\end{array}$ & $\begin{array}{l}\text { Ingestion }-(\text { excr }+ \\
\text { egest }+ \text { pred })\end{array}$ & Michaelis Menten & Fn of resp rate \\
\hline $\begin{array}{l}\text { Ducklow \& Fasham } \\
\text { (1992) }\end{array}$ & $\begin{array}{l}\text { Fn of DON and } \\
\mathrm{NH}_{4} \text { uptake }\end{array}$ & $\begin{array}{l}\text { Fn of } \mathrm{NO}_{3}, \mathrm{NH}_{4} \\
\text { mixed layer } \\
\text { depth and light }\end{array}$ & $\begin{array}{l}\text { Assim efficiency } x \\
\text { graz-excr }\end{array}$ & $\begin{array}{l}\text { Fn of prey density } \\
\text { and feeding } \\
\text { preference }\end{array}$ & Const rate \\
\hline $\begin{array}{l}\text { Baretta-Bekker et al. } \\
(1994)\end{array}$ & $\begin{array}{l}\text { Fn of uptake, respn, } \\
\text { mort, excr and graz }\end{array}$ & As for bacteria & As for bacteria & $\begin{array}{l}\text { Const } \times \text { prey } \\
\text { density }\end{array}$ & $\begin{array}{l}\text { Fn of cell } \\
\text { nutrient levels }\end{array}$ \\
\hline Davidson et al. (1995) & Not modelled & $\begin{array}{l}\text { Fn of cell } \\
\text { nutrient status }\end{array}$ & $\begin{array}{l}\text { Fn of cell } \\
\text { nutrient status }\end{array}$ & Hyp fn of prey & $\begin{array}{l}\text { Fn of cell } \\
\text { nutrient status }\end{array}$ \\
\hline
\end{tabular}

models. This is at least partly based on the desire to keep models as simple as possible. However, the inclusion of phytoplankton as a homogeneous group simulated by the simplest possible equation may be too large a generalisation. For example, sub-groupings such as the picophytoplankton are an important part of the microbial food web but are rarely modelled as a separate entity. However, when this has been undertaken (Evans 1988, Ducklow \& Fasham. 1992) model predictions have deviated from those previously obtained.

Further study of ecologically important bacterioplankton and phytoplankton species of different size and physiology is required to produce sufficiently detailed datasets to allow us to determine if models of particular species should be routinely included in our simulations (phytoplankton species which have been studied to date are those most easily cultured in the laboratory and not necessarily those of greatest environmental importance).

More physiologically detailed models which seek to explain the mechanisms of phytoplankton photosynthesis have also been developed. Such models are, in general, only applicable to steady state conditions and therefore not yet particularly suitable to simulate real data. Moreover, their high degree of complexity makes them unlikely candidates for inclusion in ecosystem models unless drastic simplification can be achieved. The inclusion of an adequate representation of light limitation of phytoplankton growth in ecosystem models is, however, important and simplified photosynthesis models have been incorporated into models of ecosystems (Fasham et al. 1990). 


\section{Models of ecosystems}

Following Platt et al. (1981) ecosystem models have generally attempted to minimise complexity by reducing the number of compartments in a model. lndeed, it would be an impossible task to include the almost infinite number of details which could influence a food web.

A potential problem when developing ecosystem models is that complex models may not behave as the sum of their component parts and aspects of a model which may be unimportant in one particular situation may become significantly more important under different conditions. For example, the cell quota model has been found to adequately represent batch culture phytoplankton growth, given certain assumptions (Droop 1979), but fails to represent datasets in which nutrient is available in pulses (Davidson \& Cunning. ham 1996). A second example is preferential ingestion of a particular prey species. This will not be evident in studies incorporating only a single prey species but may influence food web dynamics in mixed culture or natural populations.

Alternative models of the microbial food web can produce significantly different results. The model of Lancelot et al. (1991a) predicted $71 \%$ of primary production to pass through the web. However, Jones \& Henderson (1987) calculated that the bacteria-protozoan pathway was only capable of increasing zooplankton food by $7 \%$. The large discrepancy in the 2 results indicates how the dominance of different microbial processes under different conditions may drastically affect the overall behaviour of a pelagic food web. Furthermore, it highlights the importance of carrying out a sensitivity analysis to determine which parameters the model is most sensitive to, and how large an error may be introduced by poorly constrained parameter values. However, such analysis does not tell us why a particular parameter is important. An alternative method, adopted by Evans \& Parslow (1985), is to remove complexity from a model reducing it to a simpler form. The dynamics of this reduced model and the influence of particular parameters can then be studied by numerical or if possible analytical means.

A number of studies have approached the problem of producing succinct food web models by deriving analytical equations which represent the interaction between trophic levels based on cell size. Moloney \& Field $(1991 \mathrm{a}, \mathrm{b})$ found this approach allowed them to parameterise their model based on allometric relationships. Similar formulations have been produced by Thingstad \& Sakshaug (1990) and Armstrong (1994). However, this approach is hindered by the observation (Fasham 1993) that organisms with very different turnover times should not be combined within a single mode compartment

\section{Ingestion of prey}

Sensitivity analysis indicates that the function used to simulate ingestion is one of the most important in determining model performance. Therefore, the lack of rigor applied to the choice of ingestion function may result in serious shortcomings in the final model. Fortunately, unlike many other potentially attractive modifications to a model, the incorporation of alternative ingestion functions requires little increase in model complexity

Many models choose to make ingestion of prey by heterotrophic protozoa a function (usually hyperbolic) of prey density above a threshold concentration (Table 1). However, the choice of a hyperbola often seems to be based on historical precedent rather than direct observation. There remains a lack of basic laboratory data on microflagellate feeding responses with which to construct a robust hypothesis. The studies of Franks et al. (1986), Berryman (1992) and Carpenter et al. (1993) have questioned the use of hyperbolic ingestion functions. The effects of selective predation (Fasham et al. 1990), prey rejection and cannibalism by predators (Flynn et al. 1996), the form of the upper predatory closure (Steele \& Henderson 1992) and links to higher trophic levels (Ducklow 1994) may all be significant factors and require more careful consideration than they have received up to now.

Threshold prey concentrations are commonly incorporated in models (Steele \& Henderson 1992) and have a stabilising effect on predator/prey interactions (Moloney \& Field 1991a found them to damp the oscillatory response of the model). However, the need to include a threshold prey concentration may indicate a fundamental deficiency in the model. This is because a model should be able to predict observed prey thresholds rather than require them to be externally imposed. One model which achieved a stable predator/prey relationship without requiring the parameterisation of a threshold value was that of Armstrong (1994) in which a piecewise linear grazing function was employed.

The studies of Evans (1988) and Armstrong (1994) highlight the potential inadequacy of simple food chains to represent aquatic ecosystems. Evans (1988) found that extending the model of Evans \& Parslow (1985) to include 2 phytoplankton categories caused the periodicity of certain aspects of the simulation to change. However, although multiple food chains with numerous predator/prey interactions may be more realistic, it is questionable whether they will be mathematically tractable or parameterisable. 


\section{Nutrient cycling}

Caron (1991) highlighted the importance of protozoan excretion (compared to that by metazoan zooplankton) as a result of their high weight specific metabolic rates. Regeneration of nutrients and their subsequent re-utilisation is included in the majority of the models (Table 2). The simplest approach assumes that a constant fraction of ingested nutrient is regenerated. However, the rate of release may be dependent on the nutrient status of the food and the physiological status of the predator. Caron (1991) noted that the degree of starvation may also be important in determining the rate of release of a particular nutrient. Theoretical (King 1987, Newell et al. 1988, Thingstad \& Sakshaug 1990, Frost \& Franzen 1992) and simulation (Fasham et al. 1990, Moloney \& Field 1991a, b) models have confirmed the importance of nutrient cycling and highlighted its stabilising influence. These models have led to attempts to derive more detailed physiological representations of N cycling (Caron \& Goldman 1988, Anderson 1992, Davidson et al. 1995). Such models include a degree of biochemical speculation and further refinement will be necessary to allow them to be generalised sufficiently for inclusion in ocean models.

\section{Phytoplankton/bacteria}

A number of models have predicted simultaneous limitation of primary production by grazing and nutrient availability (Thingstad \& Sakshaug 1990, Frost \& Franzen 1992, Armstrong 1994). In a food web the interaction between bacteria and phytoplankton further complicates this interaction and requires careful consideration. Taylor \& Joint (1990) found bacteria to be unimportant in determining microbial loop dynamics. Yet, other studies including Pace et al. (1984), Stone (1990) and Painting et al. (1993) reached the opposite conclusion. Physical and biological conditions (or inadequate conceptual models) may be responsible for this apparent contradiction: Taylor \& Joint's (1990) model was applied to stratified systems

Table 2. Models including nutrient regeneration. N-P-H: nutrient-phytoplankton-herbivore; ML: microbial loop; FW: food web

\begin{tabular}{|c|c|c|}
\hline Model & Type & N-regeneration function \\
\hline Steele \& Henderson (1981) & $\mathrm{N}-\mathrm{P}-\mathrm{H}$ & $\begin{array}{l}\text { Both phytoplankton and zooplankton regenerate nutrients as a constant fraction } \\
\text { of intake }\end{array}$ \\
\hline Carpenter \& Kitchell (1984) & $\mathrm{N}-\mathrm{P}-\mathrm{H}$ & Constant fraction of that ingested \\
\hline $\begin{array}{l}\text { Thingstad \& Pengerud } \\
\text { (1985) (Model 1) }\end{array}$ & ML & Constant per bactera ingested \\
\hline $\begin{array}{l}\text { Thingstad \& Pengerud } \\
\text { (1985) (Model 2) }\end{array}$ & ML & Function of protozoan $\mathrm{C}: \mathrm{N}$ ratio \\
\hline Franks et al. (1986) & $\mathrm{N}-\mathrm{P}-\mathrm{H}$ & Unassimilated grazing returned to nutrient pool \\
\hline Moloney et al. (1986) & ML & Constant fraction of that ingested \\
\hline Parsons \& Kessler (1986) & FW & $\begin{array}{l}\text { No } N \text { regeneration from zooflagellates, zooplankton regenerate a constant } \\
\text { fraction of that ingested }\end{array}$ \\
\hline Frost (1987) & $\mathrm{N}-\mathrm{P}-\mathrm{H}$ & Constant fraction of that ingested \\
\hline Bartell et al. (1988) & $\mathrm{N}-\mathrm{P}-\mathrm{H}$ & Constant fraction of that ingested \\
\hline Hoffmann \& Ambler (1988) & $\mathrm{N}-\mathrm{P}-\mathrm{H}$ & $\begin{array}{l}\text { Copepod nutrient regeneration made decreasing function of food increasing } \\
\text { concentration }\end{array}$ \\
\hline Thingstad \& Sakshaug (1990) & $\mathrm{N}-\mathrm{P}-\mathrm{H}$ & Constant fraction of that ingested \\
\hline Moloney \& Field $(1991 \mathrm{a}$, b) & FW & Constant fraction of standing stock for each size class \\
\hline Fasham et al. (1990) & FW & Constant fraction of that ingested \\
\hline Taylor \& Joint (1990) & ML & Constant fraction of that ingested \\
\hline Frost \& Franzen (1992) & $\mathrm{N}-\mathrm{P}-\mathrm{H}$ & Constant fraction of that ingested \\
\hline Baretta-Bekker et al. (1994) & ML & $\begin{array}{l}\text { If nutrient content of cell exceeds a defined level regeneration occurs at a rate } \\
\text { proportional to the excess }\end{array}$ \\
\hline King $(1987)$ & FW & Constant fraction of that ingested \\
\hline Vézina \& Platt (1988) & FW & Constant fraction of that ingested \\
\hline Caron \& Goldman (1988) & $\mathrm{ML}$ & $\begin{array}{l}\text { Function of gross growth efficiency, respiration rate and C:N ratio of predator } \\
\text { and prey }\end{array}$ \\
\hline Anderson (1992) & ML & Regeneration of nitrogenous substrates required for respiration \\
\hline Davidson et al. (1995) & ML & Nutrient regeneration occurs to maintain optimal C: $N$ ratio \\
\hline
\end{tabular}


in steady state while the other models simulated transient situations where rapid changes occur.

There remains uncertainty about the behaviour of bacteria in terms of remineralisation and consumption (Thingstad 1992). Models have shown that this may be related to the interaction with phytoplankton. For example, Ducklow \& Fasham (1992) found bacteria to act as net remineralisers in netplankton dominated simulations but as net utilisers in picoplankton dominated simulations

\section{Interaction with the environment}

The physical components of coupled physical/biological models containing a representation of the microbial food web remain relatively modest. The integration of more realistic physical representations have been undertaken in other ecosystem models (Tett \& Walne 1995).

Modelling physical effects may be necessary during rapidly changing transient situations when the microbial food web may be particularly important. Models of microbial processes which have included representations of physical conditions have in general indicated a need for coupled physical/biological models. Examples include Evans \& Parslow (1985), who simulated variations in the mixed layer depth. Hoffmann \& Ambler (1988), who included frontal eddies and bottom intrusions, Newell et al. (1988), who simulated the euphotic zone and the pycnocline, and Moloney et al. (1991), who found that in coastal situations or upwelling the fraction of the primary production which reached large heterotrophs (>25 $\mathrm{mm}$ ) was more than an order of magnitude greater than in oceanic situations. The model therefore predicted the microbial loop to be an inefficient pathway to metazoa, but found it to be of significance especially in oceanic conditions (where large autotrophs do not persist) as the only available C pathway.

Most microbial models are currently point process models which take no account of spatial scale, with the cells being assumed to exist within a uniformly mixed photic zone. However, models which have incorporated transport across the thermocline of nutrients or cells (Evans \& Parslow 1985, Fasham et al. 1990) have found these processes also to be important. Models of cell transport through turbulent mixing or advection within the water column exist (Tett \& Walne 1995), but have yet to be applied to microbial food webs. However, turbulent flow regimes may influence the microbial food web as protozoans and their relatively smaller prey may be physically separated under such conditions

The timescale of the particular event to be modelled is also relevant. Hoffman \& Ambler (1988) found the timescale of frontal eddies to be too short to allow the development of a large copepod population, which did occur under different conditions. The frequency of upwelling has also been modelled: Painting et al. (1993) found either short diatom-based chains or the microbial food web to dominate the simulations depending on the imposed conditions.

The above discussion indicates that care must be exercised when interpreting model predictions, especially those from steady state models without exploration of the effect of varying physical conditions on the model. Extending a biological model to accommodate physical processes may not always be practical. However, estimation of the effect of physical forcing within a sensitivity analysis would at least indicate if there was cause for concern and more detailed modelling.

\section{Parameterisation}

An obstacle to simulating field data is parameterisation of the models.

Many of the models reviewed attempt to describe field datasets either qualitatively or quantitatively (Table 3). Unfortunately, it proved impractical to make a quantitative comparison of the parameter values used in the models reviewed, because of the variety of different modelling strategies and the different situations to which the models were applied. Although a vast amount of data pertaining to microbial processes has been collected, there remain surprisingly few time course field datasets which are suitable for the parameterisation and testing of models (Ducklow 1994). Moreover, laboratory experimentation has concentrated on a relatively few species which are easy to culture

A further problem is that the results of models which seek to simulate transient events may be sensitive to the initial conditions. Small variations in initial population levels may cause large discrepancies in the model output. Uncertainties in initial conditions can potentially be overcome by simulating a number of annual cycles and only considering results after the effect of the initial conditions has died away. However, accurate simulation of an ecosystem which may be subject to variable temperature, light and physical forcing is no easy task and may require the derivation of a much larger and more complicated model than one would desire. Furthermore, computing constraints on such a model may not allow the spatial or temporal resolution necessary to look at a short-term transient phenomenon. A more realistic solution to the problem lies in obtaining more detailed and more closely temporally resolved datasets than currently exist 
Table 3. Application of mic robial loop models to field situations. N-P-H: nutnent-phytoplankton-herbivore; ML: microbial loop; FW: food web

\begin{tabular}{|c|c|c|}
\hline Model & Type & Region and characteristıc (if any) \\
\hline Pace et al. (1984) & FW & Southeastern USA, continental shelf food web \\
\hline Newell \& Linley $(1984)$ & FW & Western English Channel \\
\hline Evans \& Parslow (1985) & $\mathrm{N}-\mathrm{P}-\mathrm{H}$ & $\begin{array}{l}\text { Eastern Subarctic Pacific and North Atlantic, with and without spring bloom, } \\
\text { respectively }\end{array}$ \\
\hline Moloney et al. (1986) & ML & English Channel \\
\hline Frost (1987) & $\mathrm{N}-\mathrm{P}-\mathrm{H}$ & Eastern Subarctic Pacific, high nutrient/low phytoplankton \\
\hline Jones \& Henderson (1987) & FW & Scottish east coast \\
\hline Wright et al. (1987) & ML & Parker Estuary, USA, salt marsh \\
\hline Hoffmann \& Ambler (1988) & N-P-H & $\begin{array}{l}\text { Southeastern USA continental shelf (no data presented), frontal eddies and } \\
\text { bottom intrusions }\end{array}$ \\
\hline Vézina \& Platt (1988) & FW & English Channel, tidal front; Celtic Sea \\
\hline Fasham et al. (1990) & FW & Station S near Bermuda \\
\hline Taylor \& Joint (1990) & $\mathrm{ML}$ & Celtic Sea; Porcupine Bight \\
\hline Christian \& Wetzel (1991) & FW & Sapelo Island, salt marsh estuary \\
\hline Lancelot et al. (1991a, b, 1993) & ML & Scotia-Weddell Sea, Antarctica, marginal ice zone \\
\hline Moloney \& Field (1991) & FW & $\begin{array}{l}\text { Agulhas Bank, coastal stratified; Benguela, coastal upwelling; southeastern } \\
\text { Atlantic, oligotrophic }\end{array}$ \\
\hline Frost \& Franzen (1992) & $\mathrm{N}-\mathrm{P}-\mathrm{H}$ & Eastern Pacific, equatorial upwelling zone \\
\hline Baretta-Bekker et al. (1994) & ML & Danish coastal waters, enclosure experiments \\
\hline
\end{tabular}

Although particular features such as upwelling or open oceans are addressed by different studies which in general give consistent results, it is uncommon for different modelling approaches to be applied to simulate the same region. Exceptions are Vézina \& Platt (1988) and Taylor \& Joint (1990) who simulated the Celtic Sea, and Evans \& Parslow (1985) and Frost (1987) who investigated the high nitrate levels in the subarctic Pacific. Detailed comparison of a number of model structures for a limited number of geographical regions of different character would provide valuable information on the relative importance of microbial processes.

\section{FUTURE DEVELOPMENTS}

\section{Advances in single species models}

As yet, most compartment type models of cell growth depend on a single yield limiting nutrient. However, the concept of a single yield limiting nutrient may be misleading Due to predation and nutrient cycling the primary producers probably never reaches a state of yield limitation. Phytoplankton and bacterial growth will be governed by the temporal and spatial availability of a number of rate limiting nutrients. The cell's ability to take up and process these nutrients will therefore determine growth rate and the rate of pas- sage of nutrients through the microbial loop to higher trophic levels. In order to determine whether the incorporation of multi-nutrient interactions is a worthwhile next step in ecosystem modelling, it is first necessary to formulate physiological models which can be tested under a range of conditions (this in turn will require accurate experimental determinations of nutrient uptake and utilisation rates). Should these models indicate the importance of intracellular processes, then effort may be applied to producing simple and succinct versions for inclusion in ecosystem models.

\section{Coupled models of $\mathrm{C}$ and $\mathrm{N}$ flux}

Many of the current ecosystem simulation models represent biomass with a single variable (such as carbon, nitrogen or cell numbers). The transfer of this quantity from 1 level of the ecosystem is then tracked. Those models which do use multiple currencies generally assume a constant conversion factor, for example between chlorophyll and $N$. However, the $C: N$ ratio of components of the food web may vary with time as organisms do not necessarily process $\mathrm{C}$ and $\mathrm{N}$ at the same rate (Vézina \& Platt 1988) and the biomass and nutrient content of prey cells ingested by a predator may vary. Moreover, the nutrient cycling models of Caron \& Goldman (1988), Anderson (1992) and Davidson et al. (1995) all found it necessary to represent both 
$C$ and $N$ when calculating protozoan nutrient regeneration. The danger of using cell numbers as the single representation of biomass was recognised by Williams (1971), and the papers of Burmaster (1979) and Droop (1979) indicate that the use of cell numbers as an indicator of biomass may produce spurious model results. Coupled models of $\mathrm{C}$ and $\mathrm{N}$ flux and the ability to represent changes per cell in these quantities therefore seems to be a minimum requirement if we are to accurately simulate the global $\mathrm{C}$ and $\mathrm{N}$ cycles.

\section{Inclusion of loss processes}

Although cell growth has been studied in detail, cell death has received less attention. If cell death is included in a model it is usually as a constant loss factor. However, death will be more significant for older cells and may cause shifts in the age structure of a population which will potentially affect growth dynamics in transient situations. Other loss processes such as the action of viruses, cell lysis and the interaction with grazers farther up the food chain remain poorly understood and therefore inadequately modelled.

\section{Mixotrophs}

The above analysis highlights algal/bacterial competition for mineral nutrients and predation pressure as important aspects of microbial food webs. Mixotrophic protists (see Fig. 1) that compete for nutrients are capable of grazing their competitors. They are therefore in the position to alter the dynamics of a food web interaction. As yet, little modelling effort has been focused on the mixotrophs, at least in part due to the lack of information on their physiology.

\section{Time lags in nutrient cycling}

A better understanding of the production and dynamics of dissolved and particulate organic matter and the availability of nutrients to bacteria and phytoplankton is necessary as this is relevant to the rate and efficiency of nutrient cycling. The rate of regeneration of nutrients is weight specific and it is a significant process for microflagellate grazers (Caron 1991). The rate of nutrient cycling (and hence the rate of transfer of biomass through the food web) may be significantly affected by the form in which $\mathrm{N}$ is regenerated. The availability of $\mathrm{N}$ to phytoplankton as amino acids, $\mathrm{NO}_{3}$. $\mathrm{NH}_{4}$ or $\mathrm{NO}_{2}$ will determine the rate of uptake and the energetic cost of processing of $N_{\text {; }}$ in addition, the spatial availability of nutrients (Moloney 1992) may be important. Furthermore, organic matter may have varying turnover times and particulates may sink out of the photic zone.

\section{Stochastic effects}

Most models of food webs are deterministic. The effect of non-deterministic variability on food web processes is therefore, as yet, poorly studied (Kremer 1983). However, uncertainty in initial conditions and parameter values may be significant especially over short timescales in rapidly changing environments. Moreover, the possibility of parameters (such as the maximum ingestion or growth ratel changing during the duration of the simulation may significantly affect model predictions

\section{CONCLUSION}

In general, experimental evidence indicating the importance of microbial processes has been confirmed by modelling studies. However, the relative importance of various processes such as grazing and nutrient cycling under different conditions remains uncertain. Simulation modelling has clarified the particular interactions which give rise to different dynamical behaviour of the food web in different geographical regions but we are still some way from a complete model framework which can cope with a variety of physical and biological conditions. A significant increase in the number of abiotic and biotic compartments in ecosystem models is unlikely to increase our understanding of model dynamics and system behaviour, although particular features may require inclusion should the biology dictate. Models retaining the same number of compartments but including coupled representations of $\mathrm{C}$ and $\mathrm{N}$ flux would be a significant advance. This is not necessarily at odds with the goal of minimising complexity in ecosystem models but does require more elegant formulations than currently exist.

Acknowledgements. This work was carried out while the author was in receipt of a grant from NERC.

\section{LITERATURE CITED}

Andersen A, Nival P (1988) A pelagic ecosystem model simulating production and sedimentation of biogenic particles: role of salps and copepods. Mar Ecol Prog Ser 44:37-50

Andersen V. Nival P, Harris R (1987) Mlodelling of a planktonic ecosystem in an enclosed water column. J Mar Biol Ass UK 67:407-430

Anderson T (1992) Modelling the influence of food $\mathrm{C}: \mathrm{N}$ ratio and respiration in growth and excretion of marine plankton and bacteria. J Plankton Res 14:1645-1671 
Armstrong RA (1994) Grazing limitation and nutrient limitation in marine ecosystems: steady state solutions of an ecosystem model with multiple food chains. Limnol Oceanogr 39:597-608

Azam F, Fenchel T, Field JG, Gray JS, Meyer-Reil LA, Thingstad $F$ (1983) The ecological role of water-column microbes in the sea. Mar Ecol Prog Ser 10:257-263

Baretta-Bekker JG, Riemann B, Baretta JW, Koch Rasmussen E (1994) Testing the microbial loop concept by comparing mesocosm data with results from a dynamical simulation model. Mar Ecol Prog Ser 106:187-198

Bartell SM, Brenkert AL, Carpenter SR (1988) Parameter uncertainty and the behaviour of a size-dependent plankton model. Ecol Model 40:85-95

Berryman AA (ed) (1992) Special feature: ratio-dependent predator-prey theory. Ecology 73:1530-1566

Billen G, Fontigny G (1987) Dynamics of a Phaeocystis-dominated spring bloom in Belgian coastal waters. II. Bacterioplankton dynamics. Mar Ecol Prog Ser 37:249-257

Boraas ME, Estep KW, Johnson PW, Sieburth JMcN (1988) Phagotrophic phototrophs: the ecological significance of mixotrophy. J Protozool 35:249-252

Bratbak G, Thingstad TF (1985) Phytoplankton-bacteria interactions: an apparent paradox? Analysis of a model system with both competition and commensalism. Mar Ecol Prog Ser 25:23-30

Bungay HR, Bungay ML (1968) Microbial interactions in continuous culture. Adv Appl Microbiol 10:269-290

Burmaster DE (1979) The unsteady continuous culture of phosphate-limited Monochrysis lutheri Droop: experimental and theoretical analysis. J Exp Mar Biol Ecol 39: $167-186$

Canale RP (1970) An analysis of models describing predatorprey interaction. Biotechnol Bioeng 12:353-378

Canale RP (1973) Experimental and mathematical modelling studies of protozoan predation on bacteria. Biotechnol Bioeng 15:707-728

Caperon J (1968a) Population growth in micro-organisms limited by food supply. Ecology 49:715-721

Caperon J (1968b) Population growth response of Isochrysis galbana to nitrate variation at limiting concentrations. Ecology 49:866-872

Caperon J (1969) Time lag in population growth response of Isochrysis galbana to a variable nitrate environment. Ecology $50: 188-192$

Capriulo GM, Sherr EB, Sherr BF (1991) Trophic behaviour and related community feeding activities of heterotrophic marine protists. In: Reid PC. Turley CM, Burkhill PH (eds) Protozoa and their role in marine processes. NATO ASI Series G: Ecological sciences, Vol 25. Springer-Verlag, Heidelberg, p 219-265

Caron DA (1991) Evolving roles of protozoa in aquatic nutruent cycles. In: Reid PC. Turley Civ, Burkhill PH (eds) Protozoa and their role in marine processes. NATO ASI Series G: Ecological sciences, Vol 25. Springer-Verlag, Heidelberg, p 387-416

Caron DA, Goldman JC (1988) Dynamics of protistan carbon and nutrient cycling. J Protozool 35:247-249

Caron DA, Goldman JC (1993) Predicting excretion rates of protozoa: reply to the comment by Landry. Limnol Oceanogr 38:472-474

Caron DA, Goldman JC, Dennett MR (1990) Carbon utilisation by the omnivorous flagellate Paraphysomonas imperforata. Limnol Oceanogr 35:192-201

Carpenter SR, Kitchell JF (1984) Plankton community structure and limnetic primary production. Am Nat 124 $159-172$
Carpenter SR, Lathrop RC; Munoz-del-Rio A (1993) Comparison of dynamic models for edible phytoplankton. Can J Fish Aquat Sci 50:1757-1767

Christian RR, Wetzel RL (1991) Synergism between research and simulation models of estuarine microbial food webs. Microb Ecol 22:111-125

Collos Y (1986) Time-lag algal growth dynamics: biological constraints on primary production in aquatic environments. Mar Ecol Prog Ser 33:193-206

Cullen JJ (1990) On models of growth and photosynthesis in phytoplankton. Deep Sea Res 37:667-683

Cullen JJ, Geider RJ, Kiefer DA, Marra J, Sakshaug E, Raven $J$ (1993) Towards a general description of phytoplankton growth for biochemical models. In: Evans GT, Fasham MJR (eds) Towards a model of ocean biogeochemical processes. NATO ASI series Vol I 10. Springer-Verlag, Heidelberg, p 153-176

Cunningham A (1984) The impulse response of Chlamydomonas reinhardii in nitrite-limited chemostat culture. Biotechnol Bioeng 26:1430-1435

Cunningham A, Maas P (1978) Time lag and nutrient storage effects in the transient growth response of Chlamydomonas reinhardii in nitrogen-limited batch and continuous culture. J Gen Microbiol 104:227-231

Davidson K, Cunningham A (1996) Accounting for nutnent processing time in mathematical models of phytoplankton growth. Limnol Oceanogr 41:779-783

Davidson K, Cunningham A, Flynn KJ (1993) Modelling temporal decoupling between biomass and numbers durng transient nitrogen-limited growth of a marine phytoflagellate. J Plankton Res 15:351-359

Davidson K, Cunningham A, Flynn KJ (1995) Predator-prey interactions between Isochrysis galbana and Oxyrrhis marina. [II. Mathematical modelling of predation and nutrient regeneration. J Plankton Res 17:465-492

Demanche JM, Curl HC, Lundy DW, Donaghy PL (1979) The rapid response of the marine diatom Skeletonema costatum to changes in external and internal nutrient concentration. Mar Biol 53:323-333

Droop MR (1968) Vitamin B-12 and marine ecology. IV. The kinetics of uptake, growth and inhibition in Monochrysis lutheri. J Mar Biol Ass UK 48:689-733

Droop MR (1975) The nutrient status of algal cells in batch culture. J Mar Biol Ass UK 55:541-555

Droop MR (1979) On the definition of $X$ and $Q$ in the cell quota model. J Exp Mar Biol Ecol 39:203

Ducklow HW (1994) Modelling the microbial food web Microb Ecol 28:303-319

Ducklow HW, Fasham MJR (1992) Bacteria in the greenhouse: modelling the role of oceanic plankton in the global carbon cycle. In: Mitchel R (ed) Environmental microbiology. Wiley-Liss, New York, p 1-31

Ducklow HW, Fasham MJR, Vezina AF (1989) Flow analysis of open sea plankton networks. In: Wulff F, Fleld JG. Mann KH (eds) Network analysis in marine ecology Springer-Verlag, Berlin, p 159-205

Ducklow HW, Taylor AH (1991) Modelling - session summary. In: Reid PC, Turley CM, Burkill PH (eds) Protozoa and their role in marine processes. NATO ASI Series G: Ecological sciences, Vol 25. Springer-Verlag, Heidelberg, p 431-442

Evans GT (1988) A framework for discussing seasonal succession and coexistence of phytoplankton species. Limnol Oceanogr 33:1027-1036

Evans GT, Parslow JS (1985) A model of annual plankton cycles. Biol Oceanogr 3:327-347

Fasham MJR (1985) Flow analysis of material in the marine euphotic zone. In: Ulanowicz RE, Platt $T$ (eds) Ecosystem 
theory for biological oceanography. Can Bull Fish Aquat Sci 213:139-162

Fasham MJR (1.993) Modelling the marine bıota. In: Heimann M (ed) The global carbon cycle. NATO ASI Series Vol I 15. Springer-Verlag, Heidelberg, p 457-504

Fasham MJR, Ducklow HW, McKelvie SM (1990) A nitrogenbased model of plankton dynamics in the ocean mixed layer. J Mar Res 48:591-639

Fenchel T (1982) Ecology of heterotrophic microflagellates. ll. Bioenergetics and growth. Mar Ecol Prog Ser 8:225-231

Fenchel T, Blackburn TH (1979) Bactena and mineral cycling. Academic Press, New York

Flynn KJ, Davidson K (1993) Predator-prey interactions between Isochrysis galbana and Oxyrrhis marina. II. Release of non-protein amines and faces during predation of Isochrysis. J Plankton Res 15:893-905

Flynn KJ, Davidson K, Cunningham A (1996) Prey selection and rejection by a microflagellate; implications for the study and operation of microbial food webs. J Exp Mar Biol Ecol 196:357-372

Franks PJS, Wroblewski JS, Flierl GR (1986) Behaviour of a simple plankton model with food-level acclimation by herbivores. Mar Biol 91:121-129

Fransz HG, Mommaerts JP, Radach G (1991) Ecological modelling of the North Sea. Neth J Sea Res 28:67-140

Fredrickson AG (1977) Behaviour of mixed cultures of organisms. Annu Rev Microbiol 31:63-87

Fredrickson AG, Jost JL, Tsuchiya HJ, Hsu PH (1973) Predator-prey interactions between Malthusian populations. J Theor Biol 38:487-526

Frost BW (1987) Grazing control of phytoplankton stock in the open subarctic Pacific Ocean: a model assessing the role of mesozooplankton, particularly the large calanoid copepods Neocalanus spp. Mar Ecol Prog Ser 39:49-68

Frost BW, Franzen NC (1992) Grazing and iron limitation in the control of phytoplankton stock and nutrient concentration: a chemostat analogue of the Pacific equatorial upwelling. Mar Ecol Prog Ser 83:291-303

Coldman JC, Caron DA, Dennett MR (1987) Regulation of gross growth efficiency and ammonium regeneration in bacteria by substrate $\mathrm{C}: \mathrm{N}$ ratio. Limnol Oceanogr 32 : $1239-1252$

Grenney DA, Bella DA, Curl HC (1973) A mathematical model of the nutrient dynamics of phytoplankton in a nitrate-limited environment. Biotechnol Bioeng 15:331-358

Grover JP (1991) Non steady-state dynamics of algal population growth: experiments with two chlorophytes. J Phycol $27: 70-79$

Hoffman EE, Ambler JW (1988) Plankton dynamics on the outer southeastern U.S. continental shelf. Part II: a timedependent biological model. J Mar Res 46:883-917

Hopkinson CS, Vallino JJ (1994) Towards the development of generally applicable models of the microbial loop in aquatic ecosystems. Microb Ecol 28:321-326

letswaart T, Flynn KJ (1995) Modelling interactions between phytoplankton and bacteria under nutrient regeneratıng conditions. J Plankton Res 17:729-744

Jones R, Henderson EW (1987) The dynamics of nutrient regeneration and simulation studies of the nutrient cycle. J Cons Int Explor Mer 43:216-236

Jost JL, Drake JF, Tsuchiya HM, Fredrickson AG (1973) Microbial food chains and food webs. $J$ Theor Biol 41. $461-484$

Jumars PA, Penry DA, Baross JA, Perry MJ, Frost BW (1989) Closing the microbial loop dissolved carbon pathway to heterotrophic bacteria from incomplete ingestion, digestion and absorption. Deep Sea Res 36:483-495
Kiefer DA, Mitchel BG (1983) A simple, steady state description of phytoplankton growth based on absorption cross section and quantum efficiency. Limnol Oceanogr 28 : $770-776$

King FD (1987) Nitrogen recycling efficiency in steady-state oceanic environments. Deep Sea Res 34:843-856

Koga S, Humphrey AE (1967) Study of the dynamic behaviour of the chemostat system. Biotechnol Bioeng 9:375-386

Kremer JN (1983) Ecological implications of parameter uncertainty in stochastic simulation. Ecol Model 18:187-207

Laake M, Dahle AB, Eberlein K, Rein K (1983) A modelling approach to the interplay of carbohydrates, bacteria and non-pigmented flagellates in a controlled ecosystem experiment with Skeletonema costatum. Mar Ecol Prog Ser 14:71-79

Lancelot C, Billen G (1985) Carbon-nitrogen relationships in nutrient metabolism of coastal marine ecosystems. Adv Aquat Microbiol 3:26.3--321

Lancelot C, Billen G, Veth C, Becquevort S, Mathot S (1991a) Modelling carbon cycling through phytoplankton and microbes in the Scotia-Weddell Sea area during sea ice retreat. Mar Chem 35:305-324

Lancelot C, Mathot S, Veth C, de Baar H (1993) Factors controlling phytoplankton ice-age blooms in the marginal icezone of the northwestern Weddell Sea during sea ice retreat 1988: field observations and mathematical modelling. Polar Biol 13:377-387

Lancelot C, Veth C, Mathot S (1991b) Modelling ice-edge phytoplankton bloom in the Scotia-Weddell sea sector of the Southern Ocean during spring 1988. J Mar Sys 2 : $333-346$

Landry MR (1993) Predicting excretion rates of microzooplankton from carbon metabolism and elemental ratios. Limnol Oceanogr 38:468-472

Laws EA, Bannister TT (1980) Nutrient and light-limited growth of Thalassiosira fluviatilis in continuous culture with implications for phytoplankton growth in the oceans Limnol Oceanogr 25:457-473

Laws EA, Chalup MS (1990) A microalgal growth model. Limnol Oceanogr 35:597-608

Lotka AJ (1925) Elements of physical biology. The Williams and Wilkins Co, Baltimore

Mayzaud P, Poulet SA (1978) The importance of the time factor in the response of zooplankton to varying concentrations of naturally occurring particulate matter. Limnol Oceanogr 23:1144-1154

Moloney CL (1992) Simulation studies of trophic flows and nutrient cycles in Benguela upwelling foodwebs. S Afr J Mar Sci 12:457-476

Moloney CL, Bergh MO, Field JG, Newell RC (1986) The effects of sedimentation and microbial nitrogen regeneration in a plankton community: a sımulation investigation. J Plankton Res 8:427-445

Moloney CL, Field JG (1991a) Modellıng carbon and nitrogen flows in a microbial plankton community. In: Reid PC, Turley CM, Burkhill PH (eds) Protozoa and their role in marine processes. NATO ASI Senes G: Ecological sciences, Vol 25. Springer-Verlag, Heidelberg, p 443-474

Moloney CL, Field JG (1991b) The size-based dynamics of plankton food webs. I. A simulation model of carbon and nitrogen flows. J Plankton Res 13:1103-1038

Moloney CL, Field JG, Lucas MI (1991) The size-based dynamics of plankton food webs. 11. Simulation of three contrasting southern Benguela food webs. J Plankton Res 13:1039-1092

Monod J (1942) Recherches sur la crolssance des cultures bactériennes. Herman, Paris 
Newell RC, Linley EAS (1984) Signuficance of microheterotrophs in the decomposition of phytoplankton: estmates of carbon and nitrogen flow based on the biomass of plankton communities. Mar Ecol Prog Ser 16:105-119

Newell RC, Moloney CL. Field JG, Lucas ML, Probyn TA (1988) Nitrogen models at the community level: plantanimal-microbe interactions. In: Blackburn TH, Sorenson J (eds) Nitrogen cycling in coastal marine environments. Wiley, New York, p 379-414

Nisbet RM, Cunningham A, Gurney WSC (1983) Endogenous metabolısm and the stability of microbial prey-predator systems. Biotechnol Bioeng 25:301-306

Pace ML, Glasser JE, Pomeroy LR (1984) A simulation analysis of continental shelf food webs. Mar Biol 82 $47-63$

Painting SJ, Moloney CL, Lucas ML (1993) Simulation and field measurements of phytoplankton-bacteria-zooplankton interactions in the southern Benguela upwelling zone. Mar Ecol Prog Ser 100:55-69

Parsons TR, Kessler TA (1986) Computer model analysis of pelagic erosystems in estuarine waters. In: Skreslet $\mathrm{S}$ (ed) The role of freshwater outflow in coastal marine ecosystems. NATO ASI Series Vol G7 Springer-Verlag, Heidelberg, p 113-120

Pengerud B, Skjoldal EF, Thingstad TF (1987) The reciprocal interaction between degradation of glucose and ecosyslem structure. Studies in mixed chemostat cultures of marine bacteria, algae, and bacterivorous nanoflagellates. Mar Ecol Prog Ser 35:111-117

Platt T, Mann KH, Ulanowicz RE (1981) Mathematical models in biological oceanography. UNESCO Press, New York

Pommeroy LR (1991) Status and future needs in protozoan ecology. In: Reid PC, Turley CM, Burkhill PH (eds) Protozoa and their role in marine processes. NATO ASI Series G: Ecological sciences, Vol 25. Springer-Verlag, Heidelberg, p 475-492

Ramkrishna D, Fredrickson AG, Tsuchiya HM (1967) Dynamics of microbial propagation: models considering inhibitors and variable cell composition. Biotechnol Bioeng 9: $129-170$

Reigman R, Mulr LR (1984) Theoretical considerations on growth kinetics and physiological adaptation of nutrientlimited phytoplankton. Arch Microbiol 140:96-100

Sambanis A, Fredrickson AG (1988) Effect of addition of wall growth to a model of ciliate-bacterial interactions. Biotechnol Bioeng 34:875-881

Sharples J, Tett P (1994) Modelling the effect of physical vanability on the midwater chlorophyll maximum. J Mar Res 52:219-238

Shuter B (1979) A model for physıological adaptatıon on unıcellular algae. J Theor Biol 78:519-552

Steele JH Henderson EW (1981) A simple plankton model. Am Nat 117:679-691.

Steele JH, Henderson EW (1992) The role of predation in plankton models. J Plankton Res 14:157-172

Stoecker DK, Cuccl TL, Hulbert EM, Yentsch CM (1986) Selective feeding by Balanion sp. (Cillata: Balanionidae) on phytoplankton that best support its growth. J Exp Mar Biol Ecol 95:113-130

This review was submitted to the editor
Stoecker DK, Evans GT (1985) Elfects of protozoan herbivory and carnivory in a microplankton food web. Mar Ecol Prog Ser 25:159-167

Stone L (1990) Phytoplankton-bacteria-protozoa interactions: a qualitative model portraying indrect effects. Mar Ecol Prog Ser 64:137-145

Sudo R, Kobayashi K, Aiba S (1975) Some experiments and analysis of a predator-prey model: interactions between Colpidium campylum and Alcaligenes faecalis in continuous and mixed culture. Biotechnol Bioeng 17:167-184

Suttle CA (1994) The significance of viruses to mortality in aquatic microbial processes. Microb Ecol 28:237-243

Taylor AH, Joint I (1990) A steady state analysis of the 'microbial loop' in stratified systems. Mar Ecol Prog Ser 59:1-17

Tett P. Droop MR (1988) Cell quota models and planktonic primary production. In: Wimpenny JWT (ed) Handbook of laboratory model systems for microbial ecosystems. Vol 2. CRC Press, Boca Raton, p 77-233

Tett P. Walne A (1995) Observations and simulations of hydrography, nutrients and plankton in the southern North Sea. Ophelia 42:371-416

Thingstad TF (1987) Utilisation of N, P and organc C by heterotrophic bacteria. I. Outlıne of a chemostat theory with a constant concept of maintenance metabolism. Mar Ecol Prog Ser 35:99-109

Thingstad TF (1992) Modelling the microbial food web structure in pelagic ecosystems. Arch Hydrobrol Beih Ergeb Limnol 37:111-119

Thingstad TF, Pengerud B (1985) Fate and effect of allochthonous organic material in aquatic microbial ecosystems. An analysis based on chemostat theory. Mar Ecol Prog Ser 21: $47-62$

Thıngstad TF, Sakshaug E (1990) Control of phytoplankton growth in nutrient recycling ecosystems. Theory and terminology. Mar Ecol Prog Ser 63:261-272

Tsuchiya HM, Drake JF, Jost JL, Fredrickson AG (1972) Predator-prey interactions of Dictyostelium discordeum and Escherichia coli in contınuous culture. J Bacteriol 110 : $1147-1153$

Umorin PP (1992) Comparison between bacterivorous flagellates and bacterivorous ciliates for food resources. Oikos 63:175-179

Vézina AF, Platt T (1988) Food web dynamics in the ocean. I. Best-estimates of flow networks using inverse methods. Mar Ecol Prog Ser 42:269-287

Villareal E, Canale RP, Akeasu Z (1975) A multigroup model for predator-prey interactions. Biotechnol Bioeng 17 : $1269-1289$

Volterra V (1926) Variazioni e fluttuazioni del numers d' individui in specie animali conviventı. Mem Accad Lineii Roma 2:31-113

Willcox DL, MaCleur JW (1979) Coevolution in predator-prey systems: a saturation kinetic model. Am Nat 113:163-183

Williams FM (1971) Dynamics of microbial populations. In Patten BC (ed) Systems analysis and simulation in ecology. Academic Press, New York, p 197-267

Wright RT, Coffin RB, Lebo ME (1987) Dynamics of planktonic bacteria and heterotrophic microflagellates in the Parker Estuary, northern Massachusetts. Cont Shelf Res 7 $1383-1397$

Manuschpt first received: January 29, 1996

Revised version accepted: October 29, 1996 